This is a so-called personal version (author's manuscript as accepted for publishing after the review process but prior to final layout and copyediting) of the article:

Mantere, Saku. What is Organizational Strategy? A Language-Based View. Journal of Management Studies, 2014, 50: 1408-1426.

Researchers are kindly asked to use the official publication in references.

\title{
What is Organizational Strategy? A Language-Based View
}

\author{
Saku Mantere \\ Hanken School of Economics, Department of Management and Organization \\ P.O. Box 479, FIN-00101 \\ saku.mantere@hanken.fi
}

Acknowledgements. This paper has been inspired by the work and input of three scholars: Henry Mintzberg has for opened our eyes to the organization in organizational strategy, Richard Whittington has asked who the strategists are, and Joep Cornelissen has provided kind encouragement to write this paper and also made crucial contributions about the language in organizations. Warm thanks also go to senior editor Bill Harley his constructive critique, to Henri Schildt and Eero Vaara for inspiring discussions around the division of linguistic labor, and to the participants of the research seminar at the McGill University Desautels Faculty of Management for their feedback. Despite all this support, the responsibility for stupid or dangerous ideas is mine and mine only.

Key words: strategy, discourse, strategy-as-practice, middle management, ambiguity, performance 


\title{
What is Organizational Strategy? A Language-Based View
}

\begin{abstract}
Under which conditions does a collective strategy exist among organizational members? Where should a scholar look for one? To offer one way to start solving these puzzles I propose a view of organizational strategy as a language game that governs the use of strategy labels at the level of the organization. Organizational strategy exhibits a division of linguistic labor, where responsibility for key concepts is assigned to particular individuals or organizational functions. Such linguistic experts oversee the proper use and maintenance of strategy language. The language-based view helps to understand linkages between institutional, network, organizational and micro level views on strategy. It also problematizes widely held intuitions regarding the relationship between strategy and organizational outcomes.
\end{abstract}


[T] here are two sorts of tools in the world: there are tools like a hammer or a screwdriver which can be used by one person; and there are tools like a steamship which require the cooperative activity of a number of persons to use. Words have been thought of too much on the model of the first sort of tool. - Hilary Putnam, The Meaning of 'Meaning', p. 229

The term strategic management has always been associated with voluntarism and free will, with what Dill (1979: 48) has called "machismo management." [---] to be truly "organizational", intentions must be broadly shared - truly collective. And yet, stated intentions can belie the real ones - even the most detailed plans may be fantasies, or simply ploys to fool the competition. Henry Mintzberg and Alexandra McHugh, Strategy Formation in an Adhocracy, p. 162

One of the most enduring and perplexing problems of strategic management is: what makes for a collective strategy in organizations? While strategies are written on pieces of paper and in power point files, organizational strategies are not pieces of paper. Organizational strategies take place in collective actions by organizational members. Strategies are achieved in work, conducted by organizational members, in coherence with each other, and over time (Mintzberg and McHugh, 1985).

The process of how strategies become shared among organizational members is not well understood, yet the nature of this process bears crucial implications for theory and practice. The notion of an 'organizational strategy' can imply a totalitarian form of management, which disrupts the sense of the organization as a community (Oakes, Townley and Cooper, 1998; Mantere and Vaara, 2008; Kornberger and Clegg, 2011). Yet, strategy formation can also act as a process where organizational communities discover their shared purpose, and which allow community members to discover meaning (Weick, 1987/2001; Mantere, 2005; Mantere and Vaara, 2008) or even hope (Carlsen, Hagen and Mortensen, 2009) in their work.

Many strategic plans, perhaps even most of them, never get realized as they were intended (Mintzberg, 1978). A strategy is "organizational" when there is coherence in organizational activities, that is, a pattern is realized in a stream of actions (Mintzberg, 1978). Yet, throughout its history, strategic management research has had a problematic relationship with organizational phenomena. Its founding scholarly fathers had a rather narrow view of organizations in their analyses. The focus of these early authors (e.g., Chandler, 1962; Andrews, 1971) was inherently managerialist: strategies were created by the leaders of the organizations, and the task of the organization was to implement those strategies. This suspicion towards organizations was amplified in the work of Michael Porter (cf. Porter, 1996), which portrays the "operational effectiveness" of an organization as a thing apart from strategic management.

The organizational challenge was first met by strategy process scholars (Pettigrew, 1992). Armed with the realization that formal strategy work was at least in part ritual and strategic plans could well be mere fantasies, strategy process researchers examined the unfolding of strategy in organizational decisions and actions. This extended the scope of organizational strategy from the ivory tower of the top management team into the far corners of the organization. Middle managers can be strategists 
(Burgelman, 1983; Floyd and Lane, 2000), and so can other organizational members (Laine and Vaara, 2007; Mantere, 2005).

The next generation of strategy scholars have extended the range of scholarship into organizational strategy by pursuing two major 'turns' in social science, the practice turn (Schatzki, 2001) and the linguistic turn (Rorty, 1992). The tendency of strategy process studies of limiting their attention to organization-level decisions and actions has compelled scholars within the strategy-as-practice program (see Johnson, Langley, Melin and Whittington, 2007; Whittington, 2006; Vaara and Whittingon, 2012) to extend their analyses both inward and outward from the organizational level, into the work of strategists, as well as the discipline of strategic management as a field-level phenomenon or 'industry' (Whittington, 2006). In a parallel development, discourse scholars, pursuing the linguistic turn, have shown an appreciation of the same three levels, exploring the language of strategy at the field, organizational and micro levels (see Vaara, 2010). Discursive authors portray strategy through a diverse set of ontological entities such as a polyphonic narrative (Barry and Elmes, 1997), as a disciplinary institution (Knights and Morgan, 1991) or as talk-based interaction (Samra-Fredericks, 2003, 2005).

More recently, research programs, focused on behavioral (Powell, Lovallo and Fox, 2011) and emotional (Huy, 2013) strategy scholarship have addressed the question of how individual psychological phenomena influence, or are aggregated into, organization-level outcomes. Parallel scholarly programs have been opened, intent on understanding crucial phenomena to strategic management such as resources (Felin and Foss, 2005) and performance (Eisenhardt, Furr and Bingham, 2010) as aggregates of micro-level phenomena.

While understanding of the nature of strategic organization has advanced in terms of increased plurality, the concept of organizational strategy has become more and more fragmented. Faced with the seemingly innocent question such as: "when does an organization not have a strategy" (Inkpen and Choudhury, 1995), a scholar, appreciative of the work done in various sub-disciplines of strategic management will find oneself at a loss. Apart from explicitly normative models such as the Balanced Scorecard (Kaplan and Norton, 1996), which tell us what organizational strategy should be, we lack integrated theoretical expressions of what an organizational strategy is.

In this essay, I will utilize concepts from contemporary analytical philosophy to develop one such expression in the form of a language-based view of the organizational strategy. I will ask three questions. The first one is simply: "What is an organizational strategy (and what is not)?" Building specifically on the concepts of language game (Wittgenstein, 1951) and division of linguistic labor (Putnam, 1975a), I will sketch out a view of the organizational strategy, and place it between the macrolevel of the strategic management discipline (Knights and Morgan, 1991) and the micro-level activities of strategists or strategy practitioners (Whittington, 2006). This allows me to suggest a way to consolidate discursive and practice-based views into a single framework.

The second question is tightly coupled with the first, and represents perhaps the key methodological question for students of organizational strategy (Jarzabkowski, 2005; Floyd and Sputtek, 2011): “Who are the strategists?" After the work of Mintzberg and Burgelman in particular, for a strategy scholar to 
look at the top management as the a priori source of organizational strategy would not be unlike the upstart detective in Robert Altman's movie Gosford Park, who seeks to solve the murder of an aristocrat by limiting his interrogations to the aristocrat guests at the lord's mansion, ignoring the large group of servants, as they had "no real connections" to the victim. The resulting methodological challenge extends the search for strategists beyond the executive floor to the whole organization. This does open a significant can of worms, however. In complex organizations, the action or inaction of a single individual may lead to tumultuous consequences at the organizational level. Small good ideas may lead to major business ventures (Lovas and Ghoshal, 2000), and small mistakes or omissions to catastrophes (Jarzabkowski, 2005). Most of them do not, however, so how do we identify individuals who have strategic agency?

My third question is: "What are the outcomes of organizational strategy?" Strategy touches upon the lives of organizational members in various ways. It can instill them with hope by endowing work practice with shared meaning (Mantere, 2005; 2008, Mantere and Vaara, 2008), yet it can also reduce human beings to human resources (Oakes, Townley \& Cooper, 1998). I will explore ways in which the language game of organizational strategy plays into this. Beyond these critical questions, the language-based view also opens up a venue for exploring the relationship of organizational strategy with the performance of the organization (Whittington, 2007). To simply equate organizational strategy with organizational performance would be to discount the unintended consequences of strategic decisions (Balogun and Johnson, 2005), as well as of course the role of luck and unpredictability in the organization's environment.

\section{Introducing Icarus Inc.}

This essay was born out of a perplexing organizational experience. I have interacted with the multinational corporation, Icarus Inc. ${ }^{1}$ repeatedly over a period of fifteen years or so. I have conducted interviews throughout their organizational units and hierarchy, hosted workshops, given lectures. During these multiple visits, I have often found myself utterly confused by seemingly ordinary words having unfamiliar meanings. I still recall one early meeting to negotiate access for a series of interviews. While the negotiations were a success, I recall leaving the company headquarters in complete bafflement. I had understood little of what was discussed. Multiple management terms were thrown about, but the terms were not used the way I was accustomed to. The practitioners appeared to understand each other, and were using the language comfortably.

My predicament had not been dissimilar to that of a soccer player who wanders into a playing field of a community that has existed in isolation from the rest of the world, and the rules of soccer have evolved beyond recognition. The ball, the field and the goalposts were still there, but the game was played in a different way. That is, I seemed to lack a basic grasp of the rules of the language game of the Icarus management (Wittgenstein, 1951).

\footnotetext{
${ }^{1}$ The name has been changed. The name Icarus refers to Danny Miller's (1990) Icarus Paradox.
} 
For a researcher, such bafflement is obviously a motivation-enhancer. Confusion tells you something needs to be made sense of, something potentially novel and theoretically interesting. So I continued with the interviews we had agreed upon. The next thing happened when I was talking to an Icarus top management team member. The topics of the interview revolved around the communication and implementation of company strategy, leadership and participation in strategy work by middle management and staff, as well as the structures and practices that affected these endeavors. At the end of a two hour interview, I concluded by asking whether something crucial had been left unaddressed. "I was really surprised that you did not ask me about change management", the executive responded. I was flummoxed. Had we not been discussing change management all long? Was strategy implementation not change management?

I started to realize that there was something particular about how language was used at Icarus. Management words were treated there the way that natural kind terms (Putnam, 1975a) - things like gold, water, snow and mountains - are treated in everyday discourse. Characterized by an engineeringbased culture, Icarus staff members exhibited a desire for clarity in language at the level of the whole corporation. Words needed to have clear and tangible extensions; they needed to be reducible to something that could be perceived objectively. This expectation did not apply only to engineering terms, but to social and managerial ones as well. Icarus exhibited a clear sense of an organization-level language game when it came to its management, with a yearning for a set of rules, shared and agreed on by all. In service of this aim, Icarus exhibited a highly developed "division of linguistic labor" (Putnam, 1975a). As natural kind terms are to be rooted in the bedrock of objective reality by the natural sciences, managerial terms such as "strategy", "quality", "process" and "change", were to be rooted in explicit organizational practices, and their meaning needed to be uniformly understood across the organization. The large and complex multinational organization of Icarus implied that this rooting involved assigning responsibility for the meaning of particular terms to specific leaders and their units. I later found out that "change management", for instance, denoted a complex set of communication and control practices, and was overseen by a particular organizational sub-function.

The maintenance of such a language game was far from simple. Organizational growth and sequential reorganizations had involved a significant intellectual struggle to maintain coherence within the structure of linguistic responsibility. At one point, a subunit responsible for "strategy" had identified more than two hundred middle managers across the corporation with the word "strategic" in their job title. The subunit was tasked with collecting these middle managers into a single training session where the meaning for the term "strategy" was to be clarified to all of them. During this time, the corporate strategy, while generally expressed in a few power point bullet points, was reported to be divisible into more than seven thousand operational measures.

While I do not think Icarus represents a middle of the road example of organizational strategy, the clarity of the organization-level language game, and the clear division of linguistic labor I encountered there is an extreme case, helpful for outlining the view of organizational strategy as a language game. 


\section{Organizational Strategy as a Language Game}

Language roots us into reality. Its powers are not limited to mirroring reality by naming objects or classes of objects in the world, as they were most famously conceived by the project of logical positivism (Rorty, 1979). Language also constitutes social reality. Denotation is only one among an innumerable amount of functions, encountered in a rich variety of "language games" (Wittgenstein, 1951).

As an introduction to the concept of "language game", consider the famous dialogue during the first meeting between Bilbo Baggins and wizard Gandalf the Grey in J.R.R. Tolkien's The Hobbit (1937/1997: 3-4):

"Good Morning!" said Bilbo, and he meant it. The sun was shining, and the grass was very green. But Gandalf looked at him from under long bushy eyebrows that stuck out further than the brim of his shady hat.

"What do you mean?" he said. "Do you wish me a good morning, or mean that it is a good morning whether I want it or not; or that you feel good this morning; or that it is a morning to be good on?"

"All of them at once," said Bilbo. "And a very fine morning for a pipe of tobacco out of doors, into the bargain.

$[---]$

"Good morning!" [Bilbo] said at last. "We don't want any adventures here, thank you! You might try over The Hill or across The Water." By this he meant that the conversation was at an end.

"What a lot of things you do use Good morning for!" said Gandalf. "Now you mean that you want to get rid of me, and that it won't be good till I move off."

The interchange between Bilbo and Gandalf suggests five different functions for the expression "good morning": (1) expressing a wish, (2) declaring a state of affairs, (3) expressing an emotion, (4) expressing a normative guideline, and (5) sending the recipient off. One suspects that the function Bilbo sought to initially achieve was the regular use of the expression, that is, (6) to greet another person.

A language game can be conceived as a rule-governed practice, integrating communication and action. To learn a language is to learn how to use words and behave properly. That is, to play a language game is to speak and act in a meaningful fashion, as governed by socially shared rules. Language games constitute and regulate social practice. They enable meaningful social interaction and the accomplishment of collective goals.

There is a sense in which organizational strategies can be conceived of as language games. A language game is treated here as a methodological tool, allowing the researcher to focus on rule-governed activity that draws the boundaries around a particular community, joined by some constitutive task or purpose (the inventor of the term, philosopher Ludwig Wittgenstein, talks about language games being rooted in 'forms of life'). When a community is regarded as a language game, its members follow rules 
that guide the proper use of language. These rules also explain the existence of the community by enabling its functions (Wittgenstein, 1951; cf. Mantere, 2010).

The notion of an organization-level language game faces criticism from two different fronts. Organizations do not have "private languages", they are not isolated from their environment, linguistically or otherwise (Mauws and Phillips, 1995). Nor are they homogenous. They consist of rich social interactions, and therefore, of multiple language games (Shotter, 2005). The difficulty of characterizing an organization, or presenting its management as a language game, is to simultaneously avoid managerialism and show appreciation for external influences. The way out of this predicament is provided by Wittgenstein's concept of "family resemblance." Language games are social worlds but not isolated ones. Rather, language games are linked together into a network of family resemblances. The concept of family resemblance not only helps one out of the predicament, but lends a meaningful theoretical framing for the language-based view on organizational strategy. Organizational language games are connected with other language games, both internal and external, forming a complex network.

Instead of producing something common to all that we call language, I am saying that these phenomena have no one thing in common which makes us use the same word for all, but that they are related to one another in many different ways. (Wittgenstein 1951: §65)

I can think of no better expression to characterize these similarities than "family resemblances"; for the various resemblances between members of a family: build, features, colour of eyes, gait, temperament, etc. etc. overlap and criss-cross in the same way. (Wittgenstein 1951: §67)

From the language-based perspective, for a strategy to be organizational, there needs to be a shared language game attached to "strategy" and associated labels (Figure 1). I hereby define "organizational strategy" as a language game that governs the use of the strategy vocabulary at the level of the organization. By "strategy labels", I follow the lead of authors such as Knights and Morgan (1991), Loewenstein and Ocasio (2003), Seidl (2007), and Paroutis and Heracleous (2013), tracing strategy back to the labels close to the word "strategy" (or the most relevant translation, such as "strategia" in Finnish) in the language of the organization in question.

Family resemblance suggests that language games can be perceived at various levels of analysis from the very micro to the very macro. Strategy labels are used in the speech of individual practitioners at the micro-level. They exist in institutionalized form in official terminology at the level of the organization. They are also used at the field-level as terminology, employed by consultants, famous CEOs, academics and other influential speakers. The language games where they are used are connected with each other into a "complicated network of similarities overlapping and criss-crossing: sometimes overall similarities, sometimes similarities of detail" (Wittgenstein, 1951: §66). The exploration of such networks of meaning is a way of overcoming theoretical boundaries in an effort of viewing all four levels simultaneously. The connections between levels of analysis have been an enduring challenge for the strategy-as-practice program (Johnson, Langley, Melin and Whittington, 2007; Whittington, 2006; Vaara and Whittington, 2012). The language-based view helps to overcome this problem. 
The notion of family resemblance also extends the reach of the agenda of strategy-as-practice scholarship as it foregrounds a macro aspect of strategic management beyond the notion of strategic management as an institutional discipline: strategy as distributed across networks (Håkansson and Snehota, 2006/1989). Strategies are produced in interaction, not only within the organization, but with one's allies and suppliers, end customers and other stakeholders. With the help of the language-based view, this added layer of complexity may be addressed in at least two ways. One may focus on the organizational network as a language game, seeking to identify a division of linguistic labor between network partners. An alternative view is to focus on the level of the organization as the root language game, and explore the network through the notion of family resemblances across the network partners. The selection between these two approaches is empirical: if the network level demonstrates a stronger division of linguistic labor than the organizations, the network should be the unit of analysis, and vice versa. A clear implication of this is also that in instances, where organizational strategy does not seem to exist in any clear sense, it may be regarded as family resembling network of more micro language games at the level of groups or subunits.

Figure 1. Organizational strategy as a language game

\begin{tabular}{|c|c|c|c|}
\hline & LEVEL OF ANALYSIS & $\begin{array}{l}\text { STRATEGY AS A LANGUAGE } \\
\text { GAME }\end{array}$ & $\begin{array}{l}\text { TYPICAL LINGUISTIC } \\
\text { EXPERTS }\end{array}$ \\
\hline \multirow{4}{*}{$\begin{array}{l}\text { NETWORKS OF } \\
\text { FAMILY } \\
\text { RESEMBLANCE } \\
\text { CONNECT } \\
\text { LINGUISTIC } \\
\text { COMMUNITIES } \\
\text { BETWEEN AND } \\
\text { ACROSS LEVELS }\end{array}$} & FIELD & $\begin{array}{l}\text { Strategic management } \\
\text { discipline: } \\
\text { Accepted orthodoxy of } \\
\text { using 'strategy' and } \\
\text { proximal labels }\end{array}$ & $\begin{array}{l}\text { Institutional gatekeepers: } \\
\text { Authors of strategy texts, } \\
\text { visible practitioners, } \\
\text { teachers }\end{array}$ \\
\hline & NETWORK & $\begin{array}{l}\text { Network strategy: } \\
\text { Rules of proper use of } \\
\text { strategy labels, followed by } \\
\text { network parties }\end{array}$ & $\begin{array}{l}\text { Owners of network-level } \\
\text { strategy practices }\end{array}$ \\
\hline & $\stackrel{\text { ORGANIZATION }}{\longrightarrow}$ & $\begin{array}{l}\text { Organizational strategy: } \\
\text { Organizationally sanctioned } \\
\text { use of strategy labels }\end{array}$ & $\begin{array}{l}\text { Owners of organizational } \\
\text { strategy practices }\end{array}$ \\
\hline & $\begin{array}{l}\text { SOCIAL GROUP } \\
\Rightarrow\end{array}$ & $\begin{array}{l}\text { Micro-strategy: } \\
\text { Shared understanding of } \\
\text { strategy concepts, enabled } \\
\text { by coherent use of strategy } \\
\text { labels }\end{array}$ & $\begin{array}{l}\text { Stable division of } \\
\text { linguistic labor possible } \\
\text { but not necessary }\end{array}$ \\
\hline
\end{tabular}

The radical implication of the language-based view is that if organizational members do not have a shared language game, regulating the use of "strategy" and associated labels, the organization does not have a strategy. I do not conceive "strategy" here a naturally occurring phenomenon, but rather as a language game played by the practitioners in the organization (see Mantere, 2005). The specific labels 
related to strategy vary across organizations, but their language games are connected to the labels produced by the "industry of strategic management" (Whittington, 2006) through relations of family resemblance. The various micro language games, evocatively presented in the work of Samra-Fredericks $(2003,2005)$, cannot be reduced to an organizational language game, nor are they controlled by the rules of an organizational language. But they are connected to the organizational level through a network of family resemblances. Organizational members may and often will consume strategies in ways that are creative and unexpected (Balogun, Jarzabkoski and Vaara, 2012; De La Ville and Monoud, 2010; Suominen and Mantere, 2010; Phillips, Sewell and Jaynes, 2008), but not totally unconnected from the language games within which strategies were produced.

\section{Division of Linguistic Labor}

The boundary around the organizational language game is vague and ambiguous, and drawing such a boundary is a methodological act, focusing attention to particular contexts of language use (Wittgenstein, 1951). How does one, then, see a strategy language game? For instance, as the organization is in one sense a network of networks, itself embedded in larger networks, how does the scholar draw a boundary around a particular social entity at a particular level of analysis, suggesting that this is where a strategy language game is present (Figure 1)?

To answer this question, I will draw on the concept of division of linguistic labor, which I experienced at Icarus. Human society is built upon such a division. The $20^{\text {th }}$ century analytic philosopher Hilary Putnam has suggested a sociolinguistic view on meaning founded on the division in linguistic labor between linguistic experts. He (1975a: 228) challenged the notion that meanings are to be found in the heads of individuals, suggesting instead that:

Every linguistic community exemplifies [linguistic] [...] division of labor [...]: that is, possesses at least some terms whose associated 'criteria' are known only to a subset of speakers who acquire the terms, and whose use by the other speakers depends upon a structured cooperation between them and the speakers in the relevant subsets.

Division of linguistic labor suggests that the rules of a complex language game are governed by multiple linguistic experts. Authority over the proper use of a term is distributed across a group of individuals. Linguistic experts are needed because all the meanings involved in contemporary vocabulary cannot be fully commanded by a single individual. We do not know the true meaning of most of the concepts we use in our daily lives. While a layperson can comfortably talk about "gold", for instance, I personally would have to consult a goldsmith to determine the authenticity of a gold watch. Yet, it would not be correct to say that I do not know the meaning of "gold", but rather that the existence of linguistic experts enables the functioning of the language games I play; "knowing the meaning of the word "gold" is not a matter of knowing that at all, but a matter of knowing how; and what you have to know how is to play your part in an intricate system of social cooperation" (Putnam, 1996: xvi). Even if I never actually do consult a goldsmith, the knowledge that such experts exist allows me to go about my business, confident that the language I use grounds me in the world around me. Words are tools which can be used to accomplish various tasks within language games. But their use requires varying levels of 
expertise, and such competence is not evenly shared across linguistic communities. Meaning is not stored as a lexicon in the heads of individuals, but exists as a social network, maintained and controlled by linguistic experts.

Traced back to the work of Plato, Adam Smith and Emile Durkheim, the notion of a division of labor is intrinsic to the meaning of an "organization." On the one hand, division of labor is perhaps the core factor that defines a social organization (Scott and Davis, 2007). On the other hand, and famously illustrated in Adam Smith's (1999/1776: 109-110) pin-making example, the productivity gains granted by division of labor explain why organizations exist, and in particular, the plentitude of organizations that have existed after the industrial revolution.

What we have not yet realized is the fact that organizations divide responsibilities, not only in work responsibilities, but also in the use of words. Organizational language games are built upon a division of linguistic labor. Wittgenstein's work on language games suggests that the rules that govern language also govern social practice. A strategy language game can therefore be expected to be linked with management practices, serving different social functions. The practices encountered in contemporary strategy processes are complex enough that their maintenance and development warrants a division of labor. Indeed, contemporary corporations have strategy units with strategy professionals who manage maintain and develop the dominant strategy practices (Paroutis and Heracleous, 2013).

Division of linguistic labor is readily apparent at the level of institutional fields, and between them. It is revealed, for instance, when the meaning of concepts is debated within or between professional communities. Consider the contested meaning of the term "planet" in the debate over Pluto's planetary status in the community of astronomers, or the debates over the diagnosis of mental illnesses during the development of new international diagnosis criteria (Schild, Mantere and Vaara, 2011). Porter's influential Harvard Business Review article on the proper use of "strategy" (Porter, 1996) where he seeks to re-institute a conceptual demarcation between "strategy" and the "operational effectiveness" is an attempt of consolidating the meaning of that important concept at the field level. It is at this level, where institutions such as professions compete over jurisdiction (Abbott, 1988). Through such debates, resources and social positions are reshuffled if linguistic expertise shifts from one expert to the next. When the debates are settled, societies possess stable meaning for the proper use of words like "planet" or "manic depressive disorder", which has a number of social and material outcomes.

The intriguing aspect of Icarus Inc. is that the organization exhibited a clear organization-level language game, apparent in a division of linguistic labor at the level of the organization. The linguistic confusions I experienced in my interactions with Icarus practitioners suggests that while the word labels appear to be shared with the external world, the rules governing their use seemed to be disconnected from the world outside. This became further evident when I ran a strategy storytelling workshop for a group of their communications professionals with a group of researcher colleagues (Küpers, Mantere and Statler, 2013). During the workshop, participants spent the morning in small groups accounting for the company history using different genres: epic, tragedy, comedy, and the afternoon drawing on these stories to narrate a desirable future journey for their company. Yet, the workshop was concluded by one of the 
senior communications managers challenging the methodology used. "I don't know what this was", he complained, "but storytelling this wasn't!"

The experience was similar to the "change management" experience that I described before. During the workshop, we had drawn on devices from narrative literature to facilitate an evocative storytelling experience. In what way was this not "storytelling?" It later turned out that the senior manager had the ambition of becoming the owner of the set of practices called "storytelling", and the practices used in the storytelling workshop had conflicted with what he had in mind. Solving the semantics of the situation also involved the authority over a new and potentially important concept.

\section{Dark Side of Organizational Strategy}

How common is organizational strategy, in the sense proposed in the language-based view? Division of linguistic labor is modeled on the use of natural kind terms. In an Icarus-like organization, the proper use for a term like "storytelling" involves the formation, reification and objectification of a set of practices. An expert needs to be assigned to promote and oversee these practices and regulate their proper use. At Icarus, "storytelling" was later developed into a road show that traveled across international units. When the road show came to town, "campfires" were built in the firm cafeteria. A campfire was a strategy discussion, hosted in the context of tent stools in a circle, facilitated by an officially accredited storyteller. That is, "storytelling" was reified into a controlled and explicit practice, owned by an organizational function, even materially anchored (Hutchins, 2005; Orlikowski, 2007) to objects such as tent stools.

But management concepts aren't necessarily like natural kinds. 'Strategy' is not like 'gold.' It is not a natural kind, but a social construction. To exist, such labels do not require a correspondence to classes of objects in a world outside the language games which create them ( $\mathrm{l}$ am happy to leave the debate to philosophers about whether or not such a mapping exists for natural kinds). The discoverer of Pluto (astronomer Clyde Tornbaugh) had to yield to the new fact that the Kuiper Belt contains quite a few objects of roughly the same size as Pluto, which undermines Pluto's position as a planet. New empirical results were able to change the accepted use of the label "Pluto". Michael Porter, on the other hand, cannot regulate the proper use by managers of the label "strategy" by referring to some salient set of facts about organizations. Despite there being an influential article in an influential journal (Porter, 1996), managers are free to use the concept of strategy as they will, and this is what their "strategy" is. Contests over the definition of a term will be rhetorical and political rather than factual in nature.

Management terms are often vague and ambiguous, their meaning imported to organizations by MBA graduates, consultants or other linguistic champions (Seidl, 2007; Vaara and Faÿ, 2011). Over time, terms such as "strategy", "quality", "process" and "change" develop local meaning and idiosyncratic use. The often implicit meanings attached to management terms form a foundation for the management culture of a firm. While the organizational language of strategy can be owned by a chosen few, it can also be created and maintained by the organizational community. But this means that the sense of an organizational language game deteriorates and ambiguity seeps in. Linguistic rules lose specificity but organizational members have more freedom in applying them as appropriate. 
A tension thus exists beneath any well-maintained language game. Power is resisted as agents seek more freedom. At one point in the Icarus storytelling workshop discussed above, one of the junior communication professionals expressed a willingness to "have more say" in matters influencing the realization of company strategy. "Are you saying you want to be empowered", a senior communications manager inquired. The junior professional got visibly agitated and retorted: "No, I don't fucking want to be empowered! I said I wanna find myself in [Icarus's] strategy!" (see Küpers, Mantere and Statler, 2013: 90). An organizational member resisting the possibility of being empowered seems counterintuitive until one recalls the local meaning attached to concepts, driven by the assignment of linguistic expertise. At face value, being empowered would seem to involve being given authority by one's superiors to influence organizational matters (Conger and Kanungo, 1988). When linguistic expertise is assigned and the meaning of a concept is attached to a defined set of organizational practices, however, the local and generic meanings of the same label drift apart. Rather than objecting to being handed authority, the junior professional was objecting to "empowerment" as a specific class of HR practices, which not only opened, but also specified and regulated the channels through which the staff could influence strategy. I observed a similar phenomenon around the concept of "strategy sharing", which consisted of a specific set of mainly unidirectional communication practices.

How should we feel about acts of resistance toward the organizational strategy? Was the junior communications professional championing a more dynamic, innovative organization? Or was he like the soccer player Diego Maradona in the 1986 world finals, who disgraced the game by scoring a goal with his hand? Normative authors (e.g., Kaplan and Norton, 1996) stress the importance of the clarity and disciplined use of key concepts for the performance of an organization. The normative role of strategy is to guide decision making at all levels of the organization (Porter, 1996), and unity in interpretation does have a significant coordinating function for smart collective action (Weick and Roberts, 1993). Robichaud, Giroux and Taylor (2004) have phrased this as an interaction between situated dialogues at the micro-level, and a collectively-shared metaconversation. This is a result of the "recursivity of communication", the embedding of existing texts into new ones. This would seem to suggest that organizational strategy would be a beneficial force in the organization as it governs the use of strategy labels.

Yet there are arguments to be made for freedom in the use of strategy labels. Ambiguous terms facilitate adaptation. When the denotation of a term is not fixed, the language can adapt more quickly to new circumstances. At the individual level, freedom to creatively consume strategy terms facilitates meaningful work for at least a part of the workforce (Mantere, 2005; Suominen and Mantere, 2010). Ambiguous terms may also act as boundary objects, facilitating the creation of new, shared language games (Astley and Zammuto, 1992).

It may be that organizations experience periods of stable language games, characterized by a stable division of linguistic labor, punctuated by periods of ambiguity, where the ownership of words is reshuffled, and new practices designed to root meanings to clear denotation, resulting in the creation of new "common ground" (Bechky, 2003). Then again, in other organizations, strategy labels may remain ambiguous. Dominated by the engineering profession, Icarus is relatively homogenous, at least compared to multi-professional contexts such as hospitals or universities. The ambiguity of strategy has 
been shown to be an enabler for the operations of pluralistic organizations. The pluralistic organization is created by interactions between different interests, often created by the co-existence of multiple professions within the organization. As different coalitions in the organizations are able to maintain their reading of ambiguous strategy texts, they are able to coexist and collaborate (Jarzabkowski, Sillince and Shaw; 2010; Sillince and Jarzabkowski, 2012). In pluralistic organizations, ambiguity in the use of important labels is caused by the coexistence of multiple language games. Multiple possible rules can be applied for the use of labels. Putnam (1975b) has addressed this phenomenon with his notion of "cluster concepts." The meaning of a cluster concept is a fuzzy set of rules of use, and no definite combination of rules is necessary or sufficient. To see a clear sense of how "strategy" may be a cluster concept, imagine a strategy discussion between two managers of belonging to the top management team of a defense contractor, one an MBA graduate, the other a West Point graduate. Both have strong and definite views of the proper use of the label "strategy", one traced back to economics, the other to warfare. Within such a plural context, the ambiguity is likely to remain inherent to the team's strategy discourse. The use of strategy labels may well be not unlike the dialogue between Bilbo and Gandalf, with key labels facing multiple potential governing rules.

\section{Conclusion and the Next Questions}

I set out to answer three questions. The first one was simply what an organizational strategy is (and what it is not). From the linguistic point of view, organizational strategy is a language game that governs the proper use of strategy labels at the level of the organization. Such organizational language games are characterized by a division of linguistic labor, as coherence in rule-following requires that the concepts are rooted in specified set of practices which require considerable effort to set up and maintain. From this perspective, an organization does not have a strategy if it does not exhibit such a division of labor - this is of course a matter of degree. In other organizations, strategy terminology may well be used, but the terms are characterized by ambiguity rather than shared interpretation and coherent rule-following. Organizational strategy is connected with other language games through family resemblance, a network of similarity with innumerable other linguistic practices. Family resemblance is a theoretical lens that allows the consolidation between conceptions of strategy at the field, network, organizational and micro-levels (Figure 1).

My second question was about finding the strategists. The answer the language-based view offers is that significant strategic actors are those who have linguistic expert roles in the strategy language game (Figure 1). The actors who control the proper use of concepts are the actors who influence the practice of strategy. The identification of these linguistic experts, and the examination of their practice, should be the goal of scholars of organizational strategy. The position of a linguistic expert endows an actor with power. The discourse literature has made it perfectly clear that strategy language is powerful (Shrivastava, 1986; Knights and Morgan, 1991; Oakes, Townley and Cooper, 1998; Laine and Vaara, 2007; Ezzamel and Willmott, 2008; Mantere and Vaara, 2008). Language games are both regulative and constitutive (Giddens, 1984). On the one hand, they regulate behavior by setting norms around the proper use of words. On the other hand, as they constitute social interaction, they enable meaningful forms of social interaction (Wittgenstein, 1951; Giddens, 1984; Shotter, 2005). One would expect that 
the more pervasive the linguistic division of labor, the clearer the enabling and constraining aspects of the strategic language game.

The third questions concerned the outcomes of organizational strategy. Why is it that some organizations have a division of linguistic labor, while others lean towards ambiguity and allow freer application of strategy concepts? These are clear empirical questions that warrant further exploration. I have noted above that Icarus is relatively homogenous compared to many other organizational contexts, and that pluralistic contexts challenge conventional wisdom about strategizing (Denis, Langley and Rouleau, 2007). Does this mean that pluralistic organizations are less likely to have organizational strategy in the sense discussed here? The natural kind organization attached to the language-based view is not necessarily a desirable type of organization for good performance. This type of organization may not even be possible in a pluralistic context. The radical outcome of this line of argument is that the existence of organizational strategy may be itself a cause of poor performance under certain conditions, and that one is less likely to find organizational strategy in plural organization.

While hardly a novel idea (Weick, 1987/2001), the notion that strategy may be harmful to an organization is very hard to accept. Strategic management is a self-legitimating discourse (Knights and Morgan, 1991; Oakes, Townley and Cooper, 1998), irresistible to contemporary academics and practitioners. It is hard to think of a well-performing organization, utterly devoid of organizational strategy (Inkpen and Choudhury, 1995). Strategy scholars have always been preoccupied with performance, and strategy-as-practice scholarship is no exception (Whittington, 2007). As there is no evidence yet to suggest that organizations with a clear division of linguistic labor are particularly innovative or perform well (indeed, these are open, empirical questions), non-strategic organizations may just as well be well-performing and/or innovative. On the basis of the Icarus example, one can even ask if a developed strategy language game is actually a symptom of the Icarus Paradox (Miller, 1990), that is, the bureaucratization and inertia, experienced by successful organizations? Is a strategic organization an organization trapped in the Icarus paradox? Was Weick (1987/2001) right in claiming that too much strategy is harmful for an organization? Or can we find counterexamples where a highly visible organization-level language game would be encountered in a very agile and dynamic firm?

Organizational strategy may have implications to organizations beyond economic performance. Organizational strategy language may become mystified, a sacred terminology used by a chosen few (Mantere and Vaara, 2008). MBA education and other elite-formation mechanisms support the creation of a terminology owned and maintained by specialists (Ghoshal, 2005; Vaara and Feÿ, 2011). Whether a strong division of linguistic labor supports such development is another open empirical question. Clarity and ambiguity both have potential constraining and enabling properties for organizational members. The overall sense of strategy which I experienced at Icarus was not an experience of an organization enslaved by a mystified strategy discourse. While there were examples of oppressive language use (as may be the case in the "empowerment" example), I also had a strong sense of commitment among the organizational members in their rule-following within the strategy language game. They could rely on shared meaning as terms had clear meanings and owners. Through the predictability it endows on social interaction, a division of linguistic labor may reinforce ontological security, which again enables strategic agency (Giddens, 1991; Mantere, 2005). 


\section{Reflections on Further Research}

These answers to the three questions conclude my language-based sketch of organizational strategy. The resulting view is far from exhaustive, and can be regarded as complementary to alternate conceptions. I look forward to exploring the linguistic view further and wish that others join in too.

How does one go about finding organizational strategy, methodologically speaking? Various existing methodological traditions contain potentially useful tools for future empirical studies. Content analytical techniques allow the surface-level exploration of organization-level strategy vocabulary (Loewerstein and Ocasio, 2003). A content analysis of the organization's official strategy texts would appear to be a good first step in exploring whether organizational strategy exists and how, as the analysis will highlight organizationally prominent strategy labels, and their interconnections within the vocabulary. This analysis will not suffice in isolation, however. An examination of linguistic experts within an organization's language game will require the analysis of naturally occurring talk in the context of the social practices of the organization. Many of the existing of qualitative research traditions are contextsensitive - ethnography, ethnomethodology, case research, narrative analysis, traditions of discourse analysis and so on. Such methods used should facilitate the simultaneous examination of labels and practices in the context of the organization.

The trick is to participate in these methodological traditions in a manner that will not lose sight of the organizational unit of analysis amidst micro-level contextual detail. While some existing traditions such as critical discourse analysis contain useful resources for inter-level analysis, the concept of family resemblance (Figure 1) lays the crucial foundation for the type of analysis suggested here. Family resemblance promotes the view that naturally occurring strategy talk in organizational micro contexts is not a platonic shadow of some organization-level strategy language, nor is the opposite the case; any more than organizational strategy language is a shadow of the language of textbook strategic management. Rather, the meanings attached to strategy labels serve different functions in their respective language games. No level has ontological primacy over another, but one needs to focus on one language game at a time.

The role for methodological tools here is therefore to help the scholar to identify at the level of the organization the key strategy labels, and the linguistic experts responsible for those labels, as well as the practices attached to the labels, governed by the experts. My experience with Icarus suggests that confusion is a good language game detector. For a researcher, a feeling of being in the presence of something alien when seemingly ordinary labels are used in an unfamiliar way warrant further exploration. Rather than simply asking informants to define the meaning of the labels - as the act of defining may prompt the informants to rack their brain in search of dictionary or academic definitions it is probably a better idea to seek out the linguistic experts in charge of confusing terms. Whose judgment do organizational practitioners ultimately yield to when the proper use of the term is determined? Is there a specific set of practices, attributed to the term, along the lines of the ones presented for "storytelling" at Icarus, and who owns those practices?

That said, when practitioners do start defining terms, without being prompted to do so by researchers, one should pay attention. Acts of definition tend to be rare in organizational life. Usually, when 
somebody starts to inquire the meaning of a term, the discussion tends to stop. The derogatory connotation attached to "semantics" by many practitioners is quite striking. "Semantics" signals discomfort, something destructive and impractical, to be avoided and sidestepped. A call to "stop the semantics" is a negative sanction that carries momentum. Why this is so is in itself interesting, but that is probably material for another story. But, when practitioners do pursue definition without heeding the warning about "semantics", linguistic expertise is also on the table. When this happens, is ownership of the term assigned to a particular person, and on what grounds? An event where definitional discourse is likely to take place naturally is when a new term is introduced into the organizational language game. This may be the importing of an existing term from another discursive domain (imagine e.g., the top management team discovering the word "innovation" for the first time), the introduction of a new term through analogical reasoning (Cornelissen and Clarke, 2010), or a genuine conceptual innovation. The processes leading to, and following the birth of new terms should be of particular interest as they are windows into the dynamics of a strategic organization. 


\section{References}

Abbott, A.D. (1988). The System of Professions: An Essay on the Division of Expert Labor. Chicago: University of Chicago Press.

Andrews, K. (1971). The Concept of Corporate Strategy. Homewood, Illinois: Dow Jones-Irwin.

Astley, W.G. and Zammuto, R.F. (1992). 'Organization Science, Managers and Language Games'. Organization Science, 3, 443-460.

Balogun, J., Jarzabkowski, P. and Vaara, E. (2011).'Selling, resistance and reconciliation: A critical discursive approach to subsidiary role evolution in MNEs'. Journal of International Business Studies, 42, 765-786.

Barry, D. and Elmes, M. (1997). 'Strategy Retold: Toward a Narrative View of Strategic Discourse'. Academy of Management Review, 22, 429-452.

Bechky, B.A. (2003). 'Sharing Meaning Across Occupational Communities: The Transformation of Understanding on a Production Floor'. Organization Science, 14, 312-330.

Burgelman, R.A. (1983). 'A Process Model of Internal Corporate Venturing in the Diversified Major Firm'. Administrative Science Quarterly, 28, 223-244.

Carlsen, A., Hagen, A.L. and Mortensen, T.F. (2009). 'Imagining Hope in Organizations: From Individual Goal-Attainment to Horizons of Relational Possibility'. In L.M Roberts and J.E. Dutton (eds.) Exploring positive identities and organizations: Building a theoretical and research. New York: Routledge.

Chandler, A.D. Jr. (1962). Strategy and Structure. Chapters in the History of the American Industrial Enterprise. Cambridge, MA: MIT Press.

Conger, J.A. and Kanungo, R.N. (1988).'The Empowerment Process: Integrating Theory and Practice'. Academy of Management Review, 13, 471-482.

Cornelissen, J.P. and Clarke, J.S. (2010). 'Imagining and Rationalizing Opportunities: Inductive Reasoning and the Creation and Justification of New Ventures'. Academy of Management Review, 35, 539-557.

De La Ville, V. and Mounoud, E. (2010). 'A narrative approach to Strategy as Practice: strategy making from texts and narratives'. In D. Golsorkhi, L. Rouleau, D. Seidl and E. Vaara (Eds.), Cambridge Handbook of Strategy as Practice (pp. 183-197). Cambridge: Cambridge University Press.

Eisenhardt, K.M., Furr, N.R. and Bingham, C.B. (2010). 'Microfoundations of Performance: Balancing Efficiency and Flexibility in Dynamic Environments'. Organization Science, 21, 1263-1273.

Ezzamel, M. and Willmott, H. (2008). 'Strategy as Discourse in a Global Retailer: A Supplement to Rationalist and Interpretive Accounts'. Organization Studies, 29, 191-217. 
Felin, T., and Foss, N.J. (2005). 'Strategic organization: A field in search of micro-foundations'. Strategic Organization, 3: 441-455.

Floyd, S.W. and Lane, P.J. (2000). 'Strategizing throughout the organization: Managing role conflict in strategic renewal'. Academy of Management Review, 25, 154-177.

Floyd, S.W., and Sputtek, R. (2011). 'Rediscovering the individual in strategy: Methodological challenges, strategies, and prospects'. In Donald D. Bergh, David J. Ketchen (ed.) Building Methodological Bridges (Research Methodology in Strategy and Management, Volume 6), Emerald Group Publishing Limited, pp.3-30.

Giddens, A. (1984). The Constitution of Society. Berkeley: California University Press.

Ghoshal, S. (2005). 'Bad Management Theories Are Destroying Good Management Practices'. Academy of Management Learning and Education, 4, 75-91.

Hutchins, E. (2005). 'Material anchors for conceptual blends'. Journal of Pragmatics, 37, 1555-77.

Huy, Q.N. (2012). 'Emotions in Strategic Organization: Opportunities for Impactful Research.' Strategic Organization, 10, 240-247.

Jarzabkowski, P. (2005) Strategy as Practice. An Activity-Based Approach. London: Sage.

Jarzabkowski, P., Sillince, J.A.A. and Shaw, D. (2010). 'Strategic ambiguity as a rhetorical resource for enabling multiple interests'. Human Relations, 63, 219-248.

Johnson, G., Langley, A., Melin, L. and Whittington, R. (2007). Strategy as Practice. Research Directions and Resources, Cambridge: Cambridge University Press.

Kaplan, R.S. and Norton, D.P. (1996). The Balanced Scorecard: Translating Strategy Into Action. Cambridge, MA: Harvard University Press.

Knights, D. and Morgan, G. (1991). 'Corporate Strategy, Organizations and Subjectivity: A Critique'. Organization Studies, 12, 251-273.

Kornberger, M. and Clegg, S. (2011). 'Strategy as performative practice: The case of Sydney 2030'. Strategic Organization, 9, 136-162.

Küpers, W., Mantere, S. and Statler, M. (2013). 'Strategy as Storytelling: A Phenomenological Exploration of Embodied Narrative Practice'. Forthcoming in the Journal of Management Inquiry.

Laine, P. and Vaara, E. (2007). 'Struggling over subjectivity: A discursive analysis of strategic development in an engineering group'. Human Relations, 60, 29-58.

Loewenstein, J. and Ocasio,W. (2003). 'Vocabularies of organizing: How language links culture, cognition, and action in organizations'. Social Science Research Network Working Paper, http://ssrn.com/abstract=813344. 
Lovas, B. and Ghoshal, S. (2000). 'Strategy as Guided Evolution'. Strategic Management Journal, 21, 875-896.

Mantere, S. (2005). 'Strategic practices as enablers and disablers of championing activity'. Strategic Organization, 3, 157-184.

Mantere, S. (2008). 'Role expectations and middle-manager strategic agency'. Journal of Management Studies, 45, 294-316.

Mantere, S. (2010). 'A Wittgensteinian perspective on strategizing'. In D. Golsorkhi, L. Rouleau, D. Seidl and E. Vaara (Eds.), Cambridge Handbook of Strategy as Practice (pp. 155-167). Cambridge: Cambridge University Press.

Mantere, S. and Vaara, E. (2008), 'On the problem of participation in strategy: A critical discursive perspective'. Organization Science, 19, 341-358.

Miller, D. (1990). The Icarus Paradox: How Excellent Organizations Can Bring About Their Own Downfall. New York: Harper.

Mauws, M.K. and Phillips, N. (1995), 'Understanding Language Games'. Organization Science, 6, 322-334.

Mintzberg, H. (1978). 'Patterns of strategy formation'. Management Science, 24, 934-948.

Mintzberg, H. and McHugh, A. (1985). 'Strategy formation in an adhocracy'. Administrative Science Quarterly, 30, 160-197.

Mintzberg, H. (2009). 'Rebuilding Companies as Communities'. Harvard Business Review, July-August, 140-143.

Oakes, L., Townley, B. and Cooper, D. (1998). 'Business planning as pedagogy: Language and control in a changing institutional field'. Administrative Science Quarterly, 43, 257-292.

Orlikowski, W.J. (2007). 'Sociomaterial practices: Exploring technology at work'. Organization Studies, 28, 1435-1448.

Paroutis, S., and Heracleous, L. (2013). 'Discourse revisited: Dimensions and employment of first-order strategy discourse during institutional adoption'. Strategic Management Journal, Forthcoming.

Pettigrew, A. M. (1992). 'The Character and Significance of Strategy Process Research'. Strategic Management Journal, 13 (Special Issue: Fundamental Themes in Strategy Process Research), 5-16.

Phillips, N., Sewell, G. and Jaynes, S. (2008). 'Applying Critical Discourse Analysis in Strategic Management Research'. Organizational Research Methods, 11, 770-789.

Porter, M. (1996). 'What is Strategy?'. Harvard Business Review, 74, November-December, 61-78.

Powell, T., Lovallo, D. and Fox, G.R. (2011). Behavioral Strategy. Strategic Management Journal, 32, 1369-1386. 
Putnam, H. (1975a). 'Meaning of 'meaning'. In Mind, Language, and Reality. Philosophical Papers Volume 2 (pp. 215-271). Cambridge: Cambridge University Press.

Putnam, H. (1975b). 'The Analytic and the Synthetic. In Mind, Language, and Reality'. Philosophical Papers Volume 2 (pp. 33-69). Cambridge: Cambridge University Press.

Putnam, H. (1996). 'Introduction'. In A. Pessin and S. Goldberg (eds), Twin Earth Chronicles. Twenty Years of Reflection on Hilary Putnam's "The Meaning of 'Meaning'". Armonk, NY: Sharpe: xV-xxii.

Robichaud, D., Giroux, H. and Taylor, J.R. (2004). 'The Metaconversation: The Recursive Property of Language as a Key to Organizing'. Academy of Management Review, 29, 617-634.

Rorty, R. (1979). Philosophy and the Mirror of Nature. Princeton, NJ: Princeton University Press.

Rorty, R. (ed.) (1992). The Linguistic Turn: Recent Essays in Philosophical Method. $2^{\text {nd }}$ Edition. Chicago: University of Chicago Press.

Samra-Fredericks, D. (2003). 'Strategizing as lived experience and strategists' everyday efforts to shape strategic direction'. Journal of Management Studies, 40, 141-174.

Samra-Fredericks, D. (2005). 'Strategic Practice, 'Discourse' and the Everyday Interactional Constitution of "Power Effects"'. Organization, 12, 803-841.

Schatzki, T.R. (2001). 'Introduction. Practice theory'. In T.R. Schatzki, K. Knorr-Cetina and E. von Savigny (eds), The Practice Turn in Contemporary Theory. London: Routledge.

Schildt, H., Mantere, S. and Vaara, E. (2011). 'Reasonability and the Linguistic Division of Labor in Institutional Work'. Journal of Management Inquiry, 20, 82-86.

Scott, W.R. and Davis, G.F. (2007). Organizations and Organizing: Rational, Natural and Open Systems Perspectives. Upper Saddle River, NJ: Pearson Education.

Seidl, D. (2007). 'General Strategy Concepts and the Ecology of Strategy Discourses: A SystemicDiscursive Perspective'. Organization Studies, 28, 197-218.

Shotter, J. (2005). "'Inside the Moment of Managing": Wittgenstein and the Everyday Dynamics of Our Expressive-Responsive Activities'. Organization Studies, 26, 113-135.

Shrivastava, P. (1986). 'Is Strategic Management Ideological?'. Journal of Management, 12, 363-377.

Sillince, J.A.A. and Jarzabkowski, P. (2012). 'Shaping Strategic Action Through the Rhetorical Construction and Exploitation of Ambiguity'. Organization Science, 23, 630-650.

Smith, A. (1999/1776). The Wealth of Nations, Books I-III. London: Penguin. 
Suominen, K. and Mantere, S. (2010). 'Consuming Strategy: The Art and Practice of Managers' Everyday Strategy Usage'. In Baum Joel A.C., Joseph Lampel (ed.) The Globalization of Strategy Research

(Advances in Strategic Management, Volume 27), Emerald Group Publishing Limited, pp. 211-245.

Vaara, E. (2010). 'Taking the linguistic turn seriously: Strategy as A multifaceted and interdiscursive phenomenon'. In Baum Joel A.C., Joseph Lampel (ed.) The Globalization of Strategy Research (Advances in Strategic Management, Volume 27), Emerald Group Publishing Limited, pp.29-50.

Vaara, E. and Faÿ, E. (2011). 'How Can a Bourdieusian Perspective Aid Analysis of MBA Education?'. Academy of Management Learning and Education, 11, 27-39.

Vaara, E. and Whittington, R. (2012). 'Strategy-as-Practice: Taking Social Practices Seriously'. Academy of Management Annals, 6, 285-336.

Weick, K.E. (1987/2001). 'Substitutes of strategy'. In Weick, K. Making Sense of the Organization.

Oxford: Blackwell.

Weick, K.E. and Roberts, K.H. (1993). 'Collective Mind in Organizations: Heedful Interrelating on Flight Decks'. Administrative Science Quarterly, 38, 357-381.

Whittington, R. (2006). 'Completing the practice turn in strategy research'. Organization Studies, 27, 613-634.

Whittington, R. (2007). 'Strategy Practice and Strategy Process: Family Differences and the Sociological Eye'. Organization Studies, 28, 1575-1586.

Wittgenstein, L. (1951). Philosophical Investigations, Oxford: Basil Blackwell. 